\title{
Review of 'The Governance of Rangelands' edited by Pedro M Herrera, Jonathan Davies and Pablo Manzano Baena
}

\author{
Claire Bedelian (D)
}

\author{
Book details \\ Herrera, PM; Davies, J and Manzano Baena P \\ The Governance of Rangelands: Collective action for sustainable pastoralism \\ Routledge, London and New York, 2014 \\ 298 pages, ISBN 9781138785144
}

Keywords: Rangelands, Governance, Pastoralists

The Governance of Rangelands is an edited collection of case studies that argues for restoring and enhancing traditional pastoral governance for the sustainable management of rangelands. Rangelands cover vast areas globally and bring together a multitude of users, requiring effective governance institutions to prevent, manage and resolve conflict. The book presents a set of 11 contrasting case studies on efforts at rebuilding pastoral governance to better manage the rangelands, support livelihoods and maintain high levels of biodiversity. Enabling approaches covered include community-based management and participatory governance built upon traditional systems, but adapted and updated to allow for innovative practices to emerge.

The book covers a range of pastoral and grassland systems globally, with case studies from Africa (6 chapters), Asia (3 chapters), the USA (1 chapter) and Europe (1 chapter). The case studies show the diversity and complexity of pastoral systems operating under different political and governance contexts and with divergent climates. The book attempts to draw out the commonalities between the case studies on the importance of local institutions and shared governance approaches for the better management of the rangelands.

To bring together such diverse contexts is by no means an easy task. There are a mix of styles and abilities in the case study chapters. Some are overly descriptive, with little

Correspondence: c.bedelian@ucl.ac.uk; clairebedelian@hotmail.com

Department of Anthropology, University College London, London, UK analysis and supporting literature, while others reflect a more rigorous approach. The introductory and synthesis chapters would be improved with greater theoretical framing, and limited attention was paid to gender or climate change, touching upon these only briefly throughout the book. Nevertheless, this book is an important contribution to the study of pastoral governance systems around the globe and provides evidence of the positive impact of good governance on livelihoods, biodiversity, economies and the rangelands themselves.

In Chapter 1, Herrera, Davies and Baena present an overview of the way pastoralists manage rangelands. They introduce and review different interpretations and definitions of governance and, in particular, consider some key principles of pastoral governance important for the improved governance of rangelands. The chapter provides an overview of pastoralism worldwide and details the ways pastoralists manage their rangelands, highlighting key aspects of traditional systems of pastoral governance.

A second introductory chapter outlines the drivers and trends in the main pastoralist regions globally and describes some common problems facing pastoralism worldwide. Many of these problems are related to the weakening of pastoral governance, which the authors argue if restored, can be the foundation of sustainable and effectively managed rangelands. The chapter is overly generalised with limited reference to the literature 
to support its points and some clumsy editing, which reduces its ability to act as a strong synthesis piece.

The following 11 chapters provide the case studies and body of evidence that form the core of the book. Chapter 3 gives a case for the revival of the traditional Hima grazing system around the Zarqa River Basin in Jordan. Haddad illustrates how the communal ownership and inclusive participatory approach of the Hima system leads to better accountability and strengthened natural resource governance.

In Chapter 4, Huntsinger, Sayre and Macaulay present a well-articulated chapter applying an analytical framework on rights and access in three different land tenure settings in the USA - Arizona, California and Texas. They show how ranchers use a web of social and political relations to maintain access to rangeland resources, regardless of whether they own, rent or are permitted to use land by the government. The three cases show the emergence of grassroots rancher organisations that positively influence the ability of ranchers to benefit from the rangelands and highlight the importance of social connections among ranchers and with management agencies.

In Chapter 5, Boutaleb and Firmian describe a community-based rangeland project in Morocco's Eastern Region aimed at rehabilitating and improving rangeland productivity. Based on the restoration of traditional social systems, the project organised herders into pastoral cooperatives responsible for collective action and the sustainable management of resources. The cooperatives are based on ethno-lineage that incorporate traditional values and help to reduce conflict. The cooperatives act as intermediaries between their members and government, thereby enabling herders to directly negotiate with government institutions to gain access to resources.

Chapter 6 looks at the numerous small areas of wetlands in drylands in the Sahel in Niger, using a case study of Lake Tabalak. These are important resource areas for a number of users - farmers, pastoralists, fishermen, natural resource collectors and wildlife, particularly birdlife. Brower gives a clear account highlighting the complexities in the management of a resource when there is no coordinated governance, which creates conflict and leads to deterioration of the wetland.

In Chapter 7, Dominguez gives an interesting and detailed account of the agdal system, a communal management regime in the High Atlas Mountains of Morocco. The chapter describes the system of opening and closing different areas for grazing and how the movements of herds are governed by a set of rules and institutions. The agdals are under threat, partly due to the expansion of intensive agriculture, in part to feed improved sheep, mainly benefiting the local elite. Dominguez argues the threat is also due to misunderstanding and poor planning by policymakers and external actors, who view these traditional systems as inferior and archaic.
Chapter 8 documents another case for the revival of the Hima system, this time in Lebanon, to address the need for a more community-based approach to rangeland management. Top-down governance in Lebanon has resulted in weak local governance and little representation and negotiation capacity of herders. Sattout describes how the revival of the Hima system allows a shift from centralised governance to a more collaborative approach, incorporating herders on the board of the Hima, where they can participate in the operation of the rangeland management.

Chapter 9 concentrates on the legal and policy environment for rangeland management in Mongolia, including the Pastureland Law, the principle law for managing the rangelands. Haman argues how laws and policies governing the rangelands have afforded little consideration of the long-term sustainable use of resources, encouraging overgrazing practices and rangeland degradation. The chapter emphasises the need for reforms to land user rights - in particular security of tenure and pasture usage fees - as a way to ensure the long-term access to resources.

Moritz and colleagues in Chapter 10 provide an excellent contribution on the governance of an open access mobile pastoral system in Cameroon. They stress the importance of keeping land open in mobile systems and for governance to focus on supporting flexibility, rather than delimiting transhumance corridors that connect wet and dry season grazing. Delimitation may reduce pastoralists' flexibility on mobility and does not necessarily prevent encroachment of cultivation, thus having the opposite effect of securing access to resources.

In Chapter 11, Roba gives an example of a restored community rangeland management approach in Garba Tula's rangelands in northern Kenya. The initiative aimed to strengthen community institutions by legalising traditional governance systems and developing participatory tools for rangeland planning. Roba attributes success of the project to communities being actively and constantly engaged in the process, working with legitimate community organisations as local partners, and being well-timed to respond to the evolving devolution processes occurring in Kenya.

In strong contrast to the other chapters, Herrera in Chapter 12 describes how it is undergrazing rather than overgrazing threatening the rangelands in northwest Spain. The depopulation of rural areas is causing abandonment of extensive livestock grazing, and a resultant loss of biodiversity and increase in wildfires. Abandonment causes a weakening of the social fabric among extensive farmers and pastoralists who are not represented in government decision-making.

Chapter 13 describes how the movement from traditional resource management institutions to privatisation 
is the major cause of resource overuse and rangeland degradation in Botswana. Buckham-Walsh and Mutambirwa provide an extensive account of Botswana's historic rangeland policies, where land policies and top-down governance has favoured privatisation over communal grazing to the benefit of wealthy farmers and ranch owners. The authors support the use of syndicates; formalised groups organised to manage grazing land around boreholes.

The final chapter gives a synthesis of lessons learnt on rebuilding pastoral governance from the preceding 11 chapters to provide guidance on the practical implementation of pastoral governance. The overarching message, that runs through the book, is that there is a need to strengthen pastoralist social fabric and overcome the weakening of traditional governance that are the primary causes of rangeland problems and conflict. Tenure security is key here, strengthening rights to land and resources, but not necessarily moving to outright ownership. Also essential is ensuring pastoralist groups have a lead role in collaborative arrangements and partnerships and are empowered to participate.

In conclusion, this volume represents a valuable body of evidence on the effectiveness of different efforts to restore traditional systems of governance, and to upgrade and adapt these to the modern context. I would recommend it to rangeland managers and practitioners implementing pastoral governance projects, as well as governance specialists and pastoralist scholars and students.

Published online: 02 November 2017

\section{Submit your manuscript to a SpringerOpen ${ }^{\mathcal{O}}$ journal and benefit from:}

- Convenient online submission

- Rigorous peer review

- Open access: articles freely available online

- High visibility within the field

- Retaining the copyright to your article

Submit your next manuscript at $\boldsymbol{\nabla}$ springeropen.com 